Економічні науки: збірник наукових прачь Луиького національного технічного університету. Серія "Регіональна економіка". Випуск 17 (67). Редкол.: відп. ред. к.е.н., професор І.В. Кривов’язюк. Луцьк: ІВВ Луцького НТУ, 2020. 348 с.

УДК 65.011

Ковальська Л.Л., д.е.н., професор

Богач К.Б., аспірант кафедри підприємництва, торгівлі та біржової діяльності

Луцький національний технічний університет

\title{
ЕКОНОМІЧНА СУТНІСТЬ ПОНЯТТЯ “ФІНАНСОВА СПРОМОЖНІСТЬ ПІДПРИЕМСТВА” НА РЕГІОНАЛЬНОМУ РІВНІ ТА МЕТОДИ ІІІ ОЦІНКИ
}

Метою даної статті $€$ подальший розвиток фінансової теорії дослідження регіону яка пов'язана з уточненням сутності поняття “фінансова спроможність” та іiі застосування як стійку економічну оцінку бюджету регіону.

В ході даного дослідження було використано такі методи: узагальнення (при уточненні змісту поняття “фінансова спроможність”), групування (при визначені та розподілу чинників впливу на фінансову спроможність), порівняльного підходу (під час вивчення основних підходів до трактування суті поняття “фінансова спроможність”); метод синтезу (для визначення сутності поняття “фінансова спроможність” шляхом поєднання різних підходів до трактування даного поняття).

В результаті дослідження було обгрунтовано та удосконалено сутність поняття “фінансова спроможність” по відношенню до бюджету регіону. Метод синтезу щодо визначення суті поняття “фінансова спроможність” дозволив виокремити статичну забезпеченість та динамічну забезпеченість, що дало змогу розкрити змістовність поняття, що вивчається. Тоді як порівняльний підхід допомагає розкрити недоліки поділу поняття “фінансова спроможність" на дані стани, що виражається у неможливість оцінки ступеня ліквідності і фінансової стійкості, а також динаміки фінансових показників.

Ключові слова: фінансова спроможність, підприємство, підприємство на регіональному рівні, чинники впливу на фінансову спроможність підприємства.

Kowalska L.L., Bohach K.B.

\section{ECONOMIC ESSENCE OF THE CONCEPT OF "FINANCIAL CAPACITY OF THE ENTERPRISE” AT THE REGIONAL LEVEL AND METHODS OF ITS ASSESSMENT}

The purpose of this article is to further develop the financial theory of the region, which is related to clarifying the essence of the concept of "financial 
Економічні науки: збірник наукових прачь Луиького національного технічного університету. Серія "Регіональна економіка". Випуск 17 (67). Редкол.: відп. ред. к.е.н., професор І.В. Кривов’язюк. Луцьк: ІВВ Луцького НТУ, 2020. 348 с.

capacity" and its application as a sustainable economic assessment of the regional budget.

The following methods were used in this study: generalization (when clarifying the meaning of the concept of "financial capacity"), grouping (in determining and distributing factors influencing financial capacity), comparative approach (in studying the main approaches to interpreting the essence of the concept of "financial capacity" ); method of synthesis (to determine the essence of the concept of "financial capacity" by combining different approaches to the interpretation of this concept).

As a result of the study, the essence of the concept of "financial capacity" in relation to the regional budget was substantiated and improved. The method of synthesis to determine the essence of the concept of "financial capacity" allowed to distinguish between static security and dynamic security, which allowed to reveal the content of the concept under study. While the comparative approach helps to reveal the shortcomings of the division of the concept of "financial capacity" into these conditions, which is expressed in the inability to assess the degree of liquidity and financial stability, as well as the dynamics of financial performance.

Key words: financial capacity, enterprise, enterprise at the regional level, factors influencing the financial capacity of the enterprise.

Ковальська Л.Л., Богач К.Б.

\section{ЭКОНОМИЧЕСКАЯ СУЩНОСТЬ ПОНЯТИЯ "ФИНАНСОВАЯ СПОСОБНОСТЬ ПРЕДПРИЯТИЯ" НА РЕГИОНАЛЬНОМ УРОВНЕ И МЕТОДЫ ЕЕ ОЦЕНКИ}

Целью данной статьи является дальнейшее развитие финансовой теории исследования региона связанной с уточнением сущности понятия "финансовая состоятельность" и ее применение как устойчивую экономическую оценку бюджета региона.

В ходе данного исследования были использованы следующие методы: обобщения (при уточнении содержания понятия "финансовая состоятельность"), группировки (при определении и распределения факторов влияния на финансовую состоятельность), сравнительного подхода (при изучении основных подходов к трактовке сущности понятия "финансовая состоятельность") метод синтеза (для определения сущности понятия "финансовая состоятельность" путем сочетания различных подходов к трактовке данного понятия).

В результате исследования было обосновано и усовершенствована сущность понятия "финансовая состоятельность" по отношению к бюджету региона. Метод синтеза по определению сущности понятия "финансовая состоятельность" позволил выделить статическую обеспеченность и динамическую обеспеченность, что позволило раскрыть содержательность понятия изучаемого языка. Тогда как сравнительный подход помогает вскрыть 
Економічні науки: збірник наукових прачь Луиького національного технічного університету. Серія "Регіональна економіка". Випуск 17 (67). Редкол.: відп. ред. к.е.н., професор І.В. Кривов'язюк. Луиьк: ІВВ Луцького НТУ, 2020. 348 с.

недостатки разделения понятия "финансовая состоятельность" на данные состояния, выражается в невозможности оценки степени ликвидности и финансовой устойчивости, а также динамики финансовых показателей.

Ключевые слова: финансовая состоятельность, пидприемство, предприятие на региональном уровне, факторы влияния на финансовую состоятельность предприятия.

Постановка проблеми. В сучасних умовах ринку, основою успішного функціонування та стабільного розвитку підприємства $є$ фінансова спроможність. Це комплексне поняття, яке включає в себе характеристику ефективності операційної діяльності, відображає здатність регіону до ефективного функціонування в умовах невизначеності фінансовий та економічно-соціальних ризиків. Також містить необхідну інформацію для інвесторів та характеризує фінансовий та інвестиційний розвиток.

Здійснене дослідження підходів до оцінювання фінансової спроможності підприємства довело, що на даний момент відсутні узгоджені методи його визначення, проте переважна більшість методів зводиться за суттю до оцінки різних складових фінансового стану. Недостатня розвиненість понятійного апарату фінансової спроможності пояснюється неоднозначністю визначення самого поняття “спроможність".

Аналіз останніх досліджень і публікацій. Поняття “спроможність" визначається як, матеріальна можливість здійснювати якусь роботу. У тлумачному словнику дане поняття розглядається в трьох різних аспектах, а саме: здатність до здійснення чого-небудь; наявність умов, сприятливих для чогонебудь, обставин, які сприяють чомусь; властивість виконувати роботу.

Великий економічний словник трактує спроможність, як передумову, схильність і вміння виконувати будь-які дії. Враховуючи вищенаведені визначення, можна побачити, що дане поняття розглядається в багатьох аспектах. Це також відноситься i до підходів науковців до визначення поняття “фінансової спроможності”. 
Економічні науки: збірник наукових прачь Луиького національного технічного університету. Серія "Регіональна економіка". Випуск 17 (67). Редкол.: відп. ред. к.е.н., професор І.В. Кривов'язюк. Луиьк: ІВВ Луцького НТУ, 2020. 348 с.

Поддерьогін А.M. пов'язує фінансову спроможність 3 фінансовим забезпеченням [1], Савицька Г.В. аналізує оборотність капіталу та здатність підприємства до саморозвитку [2]. Алексеєва А. І. та група авторів акцентують свою увагу на результатах діяльності регіону, що $\epsilon$ основним мірилом стабільного фінансового стану [3]. Методики, що розробляються державними органами влади спрямовані на оцінку фінансової спроможності в конкретних умовах: при приватизації, при залученні кредиту, банкрутстві, інвестиційній привабливості та інше [5].

На наш погляд, в даних підходах не розкривається повна суть поняття фінансова спроможність, тому можна рекомендувати власний підхід до визначення даного поняття.

Формулювання цілей статті. Метою даної статті $\epsilon$ подальший розвиток фінансової теорії дослідження регіону яка пов'язана 3 уточненням сутності поняття “фінансова спроможність" та іiі застосування як метод ефективного оцінювання бюджету регіону.

Виклад основного матеріалу дослідження 3 повним обгрунтуванням отриманих наукових результатів. Здійснене дослідження підходів до оцінювання фінансової спроможності підприємства довело, що на даний момент відсутні узгоджені методи його визначення, проте переважна більшість методів зводиться за суттю до оцінки різних складових фінансового стану. Недостатня розвиненість понятійного апарату фінансової спроможності пояснюється неоднозначністю визначення самого поняття “спроможність”. На наш погляд, в даних підходах не розкривається повна суть поняття фінансова спроможність, тому можна рекомендувати власний підхід до визначення даного поняття.

На наш погляд слід впровадити систему, згідно якої до складу фінансового аналізу входить фінансовий стан, як статична забезпеченість та фінансова спроможність, як динамічна забезпеченість. 
Економічні науки: збірник наукових прачь Луиького національного технічного університету. Серія "Регіональна економіка". Випуск 17 (67). Редкол.: відп. ред. к.е.н., професор І.В. Кривов’язюк. Луцьк: ІВВ Луцького НТУ, 2020. 348 с.

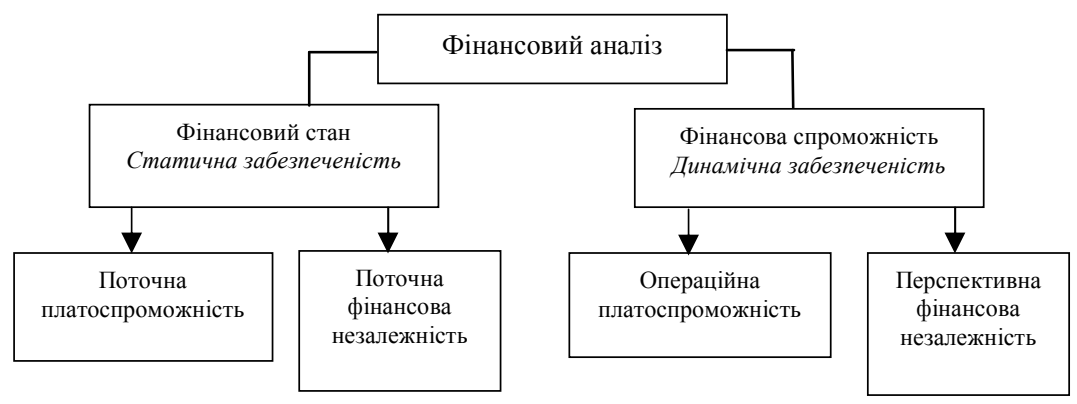

Рис. 1. Система основних понять, характеризуючих фінансову спроможність регіону (авторська розробка)

Під фінансовим станом регіону можна розуміти статичну (тобто на певний момент часу) забезпеченість необхідними фінансовими ресурсами, а під фінансовою спроможністю динамічну (постійну протягом тривалого періоду) забезпеченість. Наступним етапом буде поділ на платоспроможність та фінансову незалежність. Під платоспроможністю розуміється здатність підприємства до ефективного функціонування в умовах невизначеності фінансовий та економічно-соціальних ризиків та поділяється на поточну, тобто статичну, i операційну, тобто динамічну. Фінансова незалежність - це здатність підприємства до самофінансування. Вона поділяється на поточну фінансову незалежність (статичну) та перспективну (динамічну).

Фінансова спроможність підприємства формується протягом всього періоду діяльності. Від іï рівня залежать можливості регіону, його інвестиційна привабливість точне визначення стійкості фінансового стану належить до найбільш важливих економічних проблем, тому що надлишкова фінансова стійкість буде перешкоджати стабільному розвитку, в той час коли недостатня стійкість може призвести до проблем 3 платоспроможністю та відсутністю фінансових засобів для ефективного функціонування.[6].

Також пропонуємо виділити наступні види фінансової спроможності залежно від об'єкту: внутрішня, зовнішня та загальна. Внутрішня, формується під впливом процесів, які 
Економічні науки: збірник наукових прачь Луиького національного технічного університету. Серія "Регіональна економіка". Випуск 17 (67). Редкол.: відп. ред. к.е.н., професор І.В. Кривов'язюк. Луиьк: ІВВ Луцького НТУ, 2020. 348 с.

відбуваються в середині самого регіону, яка досягається при достатньо високих результатах його функціонування. Зовнішня, визначається діями факторів, на які не може вплинути сам регіон.

Залежно від періоду оцінки виділяють тактичну та стратегічну фінансову спроможність Тактична, характеризується забезпеченням балансу між надходженнями та витратами на даний момент часу. Стратегічна, спрямована на забезпечення розвитку регіону відповідно до поставлених цілей у довгостроковій перспективі [8].

Фінансово спроможним можна вважати регіон, який за рахунок тільки власних коштів здатний повністю забезпечити витрати. Аналіз фінансової спроможності може використовуватися інвесторами, щоб пересвідчитися в надійності регіону. Кредитори теж уважно стежать за даною характеристикою регіону, перед наданням кредитів. Банки, в деякій мірі будують свою кредитну політику на основі показників фінансової спроможності [9].

На основі проведеного аналізу пропонуємо трактувати поняття фінансова спроможність підприємства як здатність забезпечувати надходження достатнього обсягу фінансових ресурсів та формування ефективної структури їх розподілу для подолання дестабілізуючих факторів та досягнення стабільного росту підприємства у короткостроковій та довгостроковій перспективі.

Дослідження існуючих класифікацій наукового інструментарію аналізу фінансової спроможності виявило відсутність досить чітких ознак, граничну спільність виділених груп методів і інші недоліки. Часто пропонується класифікація інструментарію економічного аналізу в цілому, але не оцінки фінансової спроможності. В інших випадках використовується еволюційний підхід або виділяються досить широкі класи. Наявні класифікації не дозволяють досліджувати переваги i недоліки всього різноманіття існуючих підходів і методів оцінки фінансової спроможності [10]. 
Економічні науки: збірник наукових прачь Луиького національного технічного університету. Серія "Регіональна економіка". Випуск 17 (67). Редкол.: відп. ред. к.е.н., професор І.В. Кривов'язюк. Луиьк: ІВВ Луцького НТУ, 2020. 348 с.

У запропонованій класифікації зроблено спробу систематизації усього різноманіття методів оцінки фінансової спроможності. Виділені однорідні групи виявляють сутнісний аспект конкретних методик і дозволяють чітко уявляти їх переваги та недоліки. Це може також сприяти розробці більш обгрунтованих i якісних методів оцінки фінансової спроможності.

Перевага абсолютних методів - їх гранична простота, що виражається в мінімальних обчисленнях. Недолік неможливість оцінки ступеня ліквідності і фінансової стійкості, а також динаміки фінансових показників. У методиці аналізу абсолютної ліквідності балансу інтерпретація деяких показників абсолютно необгрунтована. Методика оцінки забезпеченості запасів i витрат джерелами фінансування, безпосередньо дозволяє оцінити не фінансову стійкість організації, а лише поточний рівень забезпеченості джерелами [11].

Коефіцієнтний підхід дозволяє оцінити рівень фінансових характеристик i ïx динаміку. Класичний підхід до оцінки платоспроможності і фінансової стійкості полягає в аналізі фінансових коефіцієнтів ліквідності і стійкості, що розраховуються на основі балансу.

Класифікаційні ознаки та відповідні класи наведені в таблиці 1.

Головний недолік даного підходу - статичний характер використовуваних показників, до уваги береться, що баланс - це наслідок, а не причина. другий недолік - необгрунтованість нормативних обмежень, що проявляється у великій їх різноманітності і невідповідність статистичними даними.

У офіційних методиках робилися спроби доповнити статичні класичні показники характеристиками оборотності i рентабельності. Домагаючись комплексності оцінки, цієї методики, проте, були по суті “простими”, тобто не були розроблені інтегруючі процедури для остаточних висновків. Головний недолік всіх “простих" методів - неможливість однозначних висновків в випадку суперечностей між різними 
Економічні науки: збірник наукових прачь Луиького національного технічного університету. Серія "Регіональна економіка". Випуск 17 (67). Редкол.: відп. ред. к.е.н., професор І.В. Кривов’язюк. Луцьк: ІВВ Луцького НТУ, 2020. 348 с.

показниками. Цей недолік вирішується в інтегральних методах [12].

Таблиця 1

Класифікація наукового інструментарію оцінки фінансової спроможності регіону

\begin{tabular}{|c|c|}
\hline Класифікаційна ознака & $\begin{array}{c}\text { Групи методів відповідно до } \\
\text { ознаки }\end{array}$ \\
\hline За типом вихідних даних & Якісні, кількісні і змішані. \\
\hline За характером вихідних даних & Нефінансові, фінансові та змішані. \\
\hline $\begin{array}{ll}\text { За } & \text { типом } \\
\text { показників } & \text { використовуваних }\end{array}$ & Абсолютні і коефіцієнтний. \\
\hline $\begin{array}{lr}\text { Залежно від } & \text { ступеня } \\
\text { інформативаності } & \text { способу } \\
\text { перетворення вихідних даних }\end{array}$ & $\begin{array}{l}\text { Просте порівняння абсолютних } \\
\text { показників. } \\
\text { Аналіз абсолютних відхилень. } \\
\text { Простий коефіцієнтний аналіз } \\
\text { (динамічний або порівняльний). } \\
\text { Нормативно-коефіцієнтний метод. } \\
\text { Метод множинних нормативів. } \\
\text { Аналіз нормованих коефіцієнтів. }\end{array}$ \\
\hline За ознакою орієнтації в часі & Ретроспективні і прогнозні. \\
\hline $\begin{array}{l}\text { Залежно від характеру моделі, на } \\
\text { якій заснований метод }\end{array}$ & Статичні і динамічні. \\
\hline За ознакою системності & Прості і інтегральні. \\
\hline $\begin{array}{l}\text { За ступенем охоплення різних } \\
\text { аспектів діяльності }\end{array}$ & Балансові та комплексні. \\
\hline $\begin{array}{lcc}\text { Залежно } & \text { від } & \text { характеру } \\
\text { iнтегрального показника } & \\
\end{array}$ & Рангові та бальні. \\
\hline
\end{tabular}

Проблема нормативних значень деяким чином вирішується в групових (рейтингових) методах. Відсутність необхідності в нормативах - основна перевага даних методів. Наприклад, може вийти так, що всі обрані регіони неплатоспроможні, тоді метод покаже лише, хто 3 них менш неплатоспроможний. Найбільш відомими $є$ метод суми місць (рангів) і метод відстаней. Кожен з цих методів має формальне обгрунтування, проте всі названі вище проблеми зберігаються і в цих методах. Даний підхід, вирішуючи певні проблеми, створює їх ще більше [13]. 
Економічні науки: збірник наукових прачь Луиького національного технічного університету. Серія "Регіональна економіка". Випуск 17 (67). Редкол.: відп. ред. к.е.н., професор І.В. Кривов'язюк. Луиьк: ІВВ Луцького НТУ, 2020. 348 с.

Використання статистичних методів для отримання інтегрального показника $\epsilon$ науково більш обгрунтованим. Загальні недоліки цих методів - проблема репрезентативності вибірки і лінійний характер моделей, що обмежує можливості врахування складних залежностей, використання підходу “чорного ящика", який дозволяє прогнозувати, оцінювати, але не аналізувати стан регіону, неможливість змістовної інтерпретації інтегральних показників [14].

Головною перевагою якісних методів, є те що вони здатні виявити передумови погіршення фінансового становища до того, як відбулися кількісні зміни в звітності. Однак, тут недоліків ще більше. В цих методиках зловживають методом експертних оцінок при визначенні значущості тих чи інших якісних чинників, системою присвоєння балів. Крім того, майже в будь-який якісної методикою, так чи інакше, доводиться використовувати кількісні параметри.

Фінансову спроможність підприємства пропонуємо оцінювати за допомогою системи показників які розглядаються в наступних етапах:

1 етап - аналіз фінансового стану підприємства.

Сюди відноситься аналіз основних показників фінансового стану, які в свою чергу розділені на групи: майновий стан підприємства; ліквідність і платоспроможність підприємства; фінансова стійкість підприємства; ділова активність підприємства; рентабельність діяльності підприємства;

2 етап - аналіз показників фінансової спроможності;

3 етап - визначення інтегрального рівня фінансової спроможності за експертно-бальною оцінкою;

4 етап - встановлення типу фінансової спроможності.

Дана методика визначення рівня фінансової спроможності підприємства дає можливість знайти найбільш вразливі місця та сформувати стратегічні та тактичні цілі діяльності підприємства. Резерви виявлення фінансової спроможності дадуть змогу забезпечити раціональне використання фінансових ресурсів та їх ефективне управління, що в свою чергу при 
Економічні науки: збірник наукових прачь Луиького національного технічного університету. Серія "Регіональна економіка". Випуск 17 (67). Редкол.: відп. ред. к.е.н., професор І.В. Кривов'язюк. Луиьк: ІВВ Луцького НТУ, 2020. 348 с.

використанні даної методики значною часткою підприємств регіону, дозволить об'єктивно оцінити сильні та слабкі сторони самого регіону.

Висновки 3 даного дослідження. В сучасних умовах ринку, основою успішного функціонування та стабільного розвитку підприємства та регіону в цілому $є$ фінансова спроможність. Це комплексне поняття, яке включає в себе характеристику ефективності операційної діяльності, відображає здатність регіону до ефективного функціонування в умовах невизначеності фінансовий та економічно-соціальних ризиків. Також містить необхідну інформацію для інвесторів та характеризує фінансовий та інвестиційний розвиток.

Здійснене дослідження підходів до оцінювання фінансової спроможності підприємства довело, що на даний момент відсутні узгоджені методи його визначення, проте переважна більшість методів зводиться за суттю до оцінки різних складових фінансового стану. Недостатня розвиненість понятійного апарату фінансової спроможності пояснюється неоднозначністю визначення самого поняття "спроможність".

Здійснений в роботі аналіз підходів учених до визначення сутності поняття “фінансова спроможність” допоміг виокремити статичну забезпеченість та динамічну забезпеченість, що дало змогу розкрити змістовність поняття, що вивчається. Тоді як порівняльний підхід допомагає розкрити недоліки поділу поняття “фінансова спроможність" на дані стани, що виражається у неможливість оцінки ступеня ліквідності i фінансової стійкості, а також динаміки фінансових показників.

Метод групування, який був застосований, дозволив встановити оптимальну методику оцінювання фінансової спроможності підприємства регіону, що в свою чергу призведе до встановлення об'єктивної оцінки діяльності самого регіону.

\section{Список бібліографічного опису}

1. Поддерьогін А.М. Фінансови менеджмент. 2005. С. 384-391.

2. Савицька Г.В. Анализ хозяйственной деятельности, ИНФРАM. 2004. $425 \mathrm{c}$.

3. Алексеева А.И., Васильев Ю.В., Малеева А.В., Комплексный экономический анализ хозяйственной деятельности. КноРус. 2007. С. 38-42. 
Економічні науки: збірник наукових прачь Луиького національного технічного університету. Серія "Регіональна економіка". Випуск 17 (67). Редкол.: відп. ред. к.е.н., професор І.В. Кривов’язюк. Луцьк: ІВВ Луцького НТУ, 2020. 348 с.

4. Камінська I.M. Інтегральна оцінка фінансової спроможності регіонів України, Актуальні проблеми економіки. 2008. №5. С. 92-101.

5. Костирко Р.О. Нормативно-правове забезпечення контролю та аналізу фінансової стійкості підприємства. Економіка та право. 2009. №3. C. $173-181$.

6. Василенко А.В. Менеджмент устойчивого развития предприятий. Центр учебной літератури. 2015. 648 с.

7. Іванов В.Л., Малов В.А. Забезпечення організаційно-економічної стійкості промислового підприємства. Економіка. Менеджмент. Підприємство. 2010. №22. С. 32-39.

8. Цал-Цалко Ю.С. Фінансова звітність підприємства та іiі аналіз. ЦУЛ. 2012. 359 с.

9. Партин Г.О. Особливості впливу основних чинників на фінансову стійкість підприємства в умовах фінансово-економічної кризи. Збірник науково-технічних праць Національного лісотехнічного університету Украӥни. 2010. №10. C. 276-279.

10. Островська О.А. Фінансовий стан та фінансова стійкість підприємств: теоретичні аспекти визначення їх суті. Стратегія економічного розвитку Украӥни. 2012. №4. 182 с.

11. Квасницька Р. Інструментарій та методи оптимізації цільової структури підприємства. Економіст. 2005. №5. С. 73-75.

12. Котляр М.Л. Аналіз фінансового стану підприємства. Фінанси Украӥни. 2004. №5. С. 99-105.

13. Марцин В.С. Надійність, платоспроможність та фінансова стійкість -основні складові оцінки фінансового стану підприємства. Економіка. Фінанси. Право. 2008. №7. С. 26-30.

14. Имангулов В.Р. Система показателей финансовой устойчивости организации и анализ действующих методик их определения. Aydum $u$ финансовый анализ. 2010. №5. С. 94-100.

\section{References}

1. Podderogin A.M. Financial management. 2005. pp. 384-391.

2. Savitska G.V. Analysis of economic activity, INFRA-M. 2004. 425 p.

3. Alekseeva A.I., Vasiliev Y.V., Maleeva A.V., Complex economic analysis of economic activity. KnoRus. 2007.pp. 38-42.

4. Kaminska I.M. Integral assessment of the financial capacity of the regions of Ukraine, Current economic problems. 2008. vol. 5. pp. 92-101.

5. Kostyrko R.O. Regulatory and legal support of control and analysis of financial stability of the enterprise. Economics and law. 2009. vol. 3. pp. 173-181.

6. Vasilenko A.V. Management of sustainable development of enterprises. Center for Educational Literature. 2015. 648 p.

7. Ivanov V.L., Malov V.A. Ensuring organizational and economic stability of an industrial enterprise. Economy. Management. Enterprise. 2010. vol. 22. pp. 32-39.

8. Tsal-Tsalko Y.S. Financial statements of the enterprise and its analysis. 
Економічні науки: збірник наукових прачь Луиького національного технічного університету. Серія "Регіональна економіка". Випуск 17 (67). Редкол.: відп. ред. к.е.н., професор І.В. Кривов’язюк. Луцьк: ІВВ Луцького НТУ, 2020. 348 с.

CUL. 2012. 359 p.

9. Partin G.O. Features of the influence of the main factors on the financial stability of the enterprise in the financial and economic crisis. Collection of scientific and technical works of the National Forestry University of Ukraine. 2010. vol. 10. pp. 276-279.

10. Ostrovskaya O.A. Financial condition and financial stability of enterprises: theoretical aspects of determining their essence. Strategy of economic development of Ukraine. 2012. vol. 4. 182 p.

11. Kvasnytska R. Tools and methods for optimizing the target structure of the enterprise. Economist. 2005. vol. 5. pp. 73-75.

12. Kotlyar M.L. Analysis of the financial condition of the enterprise. Finance of Ukraine. 2004. vol. 5. pp. 99-105.

13. Marcin V.S. Reliability, solvency and financial stability - the main components of assessing the financial condition of the enterprise. Economy. Finances. Law. 2008. vol. 7. pp. 26-30.

14. Imangulov V.R. System of indicators of financial stability of the organization and the analysis of operating methods of their definition. Audit and financial analysis. 2010. vol. 5. pp. 94-100. 